\title{
Penambahan Tepung Ubi Ungu (Ipomea batatas L.) Terhadap Sifat Organoleptik dan Kimia dalam Pembuatan Pizza
}

\section{The Study of Purple Sweat Potato Flour (Ipomea batatas L.) Addition on Organoleptic and Chemical Properties In Making of Pizza}

\author{
Andra Tersiana Wati ${ }^{1}$ dan Ertha Martha Intani ${ }^{1}$ \\ ${ }^{1}$ Universitas Nahdlatul Ulama Yogyakarta \\ ${ }^{\square}$ Komunikasi Penulis, email: andratersiana@unu-jogja.ac.id \\ DOI:http://dx.doi.org/10.23960/jtep-l.v10i4.488-495
}

Naskah ini diterima pada 27 Oktober 2021; revisi pada 29 November 2021; disetujui untuk dipublikasikan pada 9 Desember 2021

\begin{abstract}
Purple sweet potato flour (Ipomea batatas L.) can be developed as a partial substitute in processing wheat flourbased food products such as pizza. Pizza has a thin round shape with the addition of various toppings on it. This study aims to determine the effect of adding purple sweet potato flour in pizza making on the organoleptic and chemical characteristics of the resulting pizza product. There were 6 variations of pizza with purple sweet potato flour substitution concentration of $0 \%, 10 \%, 20 \%, 30 \%, 40 \%$ and $50 \%$. This study used a completely randomized design method with two repetitions. The resulting pizzas were tested sensory including preference tests as well as differentiation tests (sweet pota to flavor, sweet potato aroma, dark purple color, and soft texture). Furthermore, the selected pizzas were analyzed chemically, including proximate analysis and antioxidant activity. Based on statistical tests showed that the addition of purple sweet potato flour was quite favorable at a concentration of $30 \%$ with a water content of $44.45 \%$, ash content of $3.48(\% \mathrm{db})$, protein content 10.26 (\% db), carbohydrate content $74.89(\% \mathrm{db})$ with energy 239.58 (cal/100 g) and antioxidant activity (RSA) $71.26 \%$.
\end{abstract}

Keywords: antioxidant activity, pizza, purple sweat potato flour, purple sweat potato, sensory test

\begin{abstract}
ABSTRAK
Tepung ubi ungu (Ipomea batatas $L$.) dapat dikembangkan sebagai substitusi parsial pada pengolahan produk pangan berbasis tepung terigu seperti pizza. Pizza memiliki bentuk bundar tipis dengan tambahan aneka topping di atasnya. Penelitian ini bertujuan untuk mengetahui pengaruh penambahan tepung ubi ungu pada pembuatan pizza terhadap karakteristik organoleptik dan kimia produk pizza yang dihasilkan. Terdapat 6 variasi pizza dengan konsentrasi subtitusi tepung ubi ungu $0 \%, 10 \%, 20 \%, 30 \%, 40 \%$ dan $50 \%$. Metode rancangan acak lengkap dengan dua kali pengulangan diterapkan dalam penelitian ini. Pizza yang dihasilkan diujikan secara organoleptik meliputi uji kesukaan serta tes pembedaan (rasa ubi, aroma ubi, warna ungu tua, dan tekstur empuk). Selanjutnya, pizza terpilih dianalisis secara kimia, meliputi analisis proksimat serta aktivitas antioksidan. Analisis data dilakukan dengan menggunakan uji one way ANOVA dan uji lanjut Duncan pada selang kepercayaan $5 \%$. Berdasarkan uji statistik menyatakan bahwa substitusi parsial tepung ubi ungu cukup disukai pada konsentrasi 30\% dengan kadar air 44,45 \%, kadar abu 3,48 (\% db), kadar protein 10,26 (\% db), kadar karbohidrat by difference 74,89 (\% db) serta aktivitas antioksidan (RSA) 71,26\%.
\end{abstract}

Kata Kunci: aktivitas antioksidan, pizza, tepung ubi ungu, ubi ungu, uji organoleptik

\section{PENDAHULUAN}

Ubi ungu adalah produk pertanian yang prospektif untuk pengembangan sumber pangan lokal di Indonesia. Komposisi kimia ubi ungu terdiri atas kadar air $(61,64 \%)$, kadar abu $(1,62 \%)$, kadar protein $(4,40 \%)$, kadar lemak
$(0,75 \%)$ dan karbohidrat $(93,23 \%)$ dalam 100 gram bahan (Murtiningsih, 2011). Ubi ungu mengandung antosianin yang bermanfaat sebagai penangkap radikal bebas. Kadar antosianin pada ubi ungu tua senilai $138,15 \mathrm{mg}$ dan 9,89 mg per 100 gram basis kering pada ubi ungu muda (Husna et al., 2013). 
Ketersediaan ubi ungu melimpah, namun cepat rusak karena masa simpan optimal 5 - 6 bulan dari masa panen. Untuk mengatasi kerusakan tersebut, teknologi proses yang dapat dilakukan adalah mengolah menjadi tepung (Darmawansyah dan Ninsix, 2016). Rekayasa proses yang dilakukan pada ubi ungu selain bermanfaat untuk memperpanjang umur simpan, juga mempermudah pemanfataan tanpa mengurangi nilai gizi. Dalam bentuk tepung, potensi ubi jalar ungu sebagai sumber antioksidan dapat dinikmati masyarakat secara fleksibel. Pemanfaatannya dapat digunakan dalam pembuatan es krim, mie, roti, maupun cake. Pengembangan aneka ragam tepung lokal perlu mendapat perhatian serius, guna mengurangi konsumsi tepung terigu.

Tepung ubi ungu adalah bahan industri pangan setengah jadi yang dapat digunakan sebagai komponen yang fungsinya dapat mensubtitusi tepung terigu, salah satunya dalam pembuatan pizza. Pizza merupakan roti bundar yang berbentuk pipih yang dibuat dari beberapa bahan seperti tepung terigu, air, gula, garam, yeast, dan minyak zaitun melalui tahapan pembentukan adonan, fermentasi, dan pemanggangan. Penelitian ini dilaksanakan untuk mengidentifikasi penambahan tepung ubi ungu terhadap karakteristik organoleptik pizza serta karakteristik kimia meliputi kadar air, kadar abu, kadar protein, kadar karbohidrat (by difference) serta aktivitas antioksidan pada formula penambahan tepung ubi ungu yang masih disukai oleh panelis.

\section{BAHAN DAN METODE}

Riset ini dilakukan di Laboratorium Baking, Program Studi Bisnis Jasa Makanan, Universitas Ahmad Dahlan dan Laboratorium Terpadu, Fakultas Industri Halal, Universitas Nahdlatul Ulama Yogyakarta pada September - Oktober 2021. Alat yang digunakan adalah hand mixer, oven desk, proofer, pisau, cutting board, garpu, mixing bowl, timbangan digital, gelas ukur, oven, pizza cutter, dan loyang. Bahan yang digunakan dalam penelitian ini adalah tepung ubi ungu, tepung terigu protein tinggi, gula kristal putih, garam, yeast instan, bread improver, margarin, susu bubukfullcream, saos tomat, jagung manis segar, paprika hijau segar, bawang bombay segar dan sosis.

Penelitian ini dilakukan dengan metode rancangan acak lengkap satu faktor, yaitu penambahan tepung ubi ungu pada enam taraf. Rasio tepung ubi ungu dibanding tepung terigu yaitu $0: 10 ; 1: 9 ; 2: 8 ; 3: 7 ; 4: 6$ dan $5: 5$ dengan 2 kali ulangan perlakuan dan analisis. Formulasi pizza disajikan pada Tabel 1 .

Tabel 1. Formulasi Pizza

\begin{tabular}{lcccccc}
\hline \multirow{1}{*}{ Nama Bahan } & Rasio & Rasio & Rasio & Rasio & Rasio & Rasio \\
& $\mathbf{0 : 1 0}$ & $\mathbf{1 : 9}$ & $\mathbf{2 : 9}$ & $\mathbf{3 : 7}$ & $\mathbf{4 : 6}$ & $\mathbf{5 : 5}$ \\
\cline { 2 - 7 } & gram & gram & gram & gram & gram & gram \\
\hline Tepung terigu & 500 & 450 & 400 & 350 & 300 & 250 \\
Tepung ubi ungu & 0 & 50 & 100 & 150 & 200 & 250 \\
Yeast instan & 11 & 11 & 11 & 11 & 11 & 11 \\
Margarin & 60 & 60 & 60 & 60 & 60 & 60 \\
Air & 275 & 275 & 275 & 275 & 275 & 275 \\
Gula pasir & 50 & 50 & 50 & 50 & 50 & 50 \\
Garam & 5 & 5 & 5 & 5 & 5 & 5 \\
Susu bubuk fullcream & 25 & 25 & 25 & 25 & 25 & 25 \\
Bread improver & 5 & 5 & 5 & 5 & 5 & 5 \\
Topping: & & & & & 60 & 60 \\
Paprika hijau & 60 & 60 & 60 & 60 & 60 & 75 \\
Bawang bombay & 75 & 75 & 75 & 75 & 75 & 100 \\
Sosis & 100 & 100 & 100 & 100 & 100 & 200 \\
Saus tomat & 200 & 200 & 200 & 200 & 200 & 100 \\
Jagung manis & 100 & 100 & 100 & 100 & 100 & \\
\hline
\end{tabular}




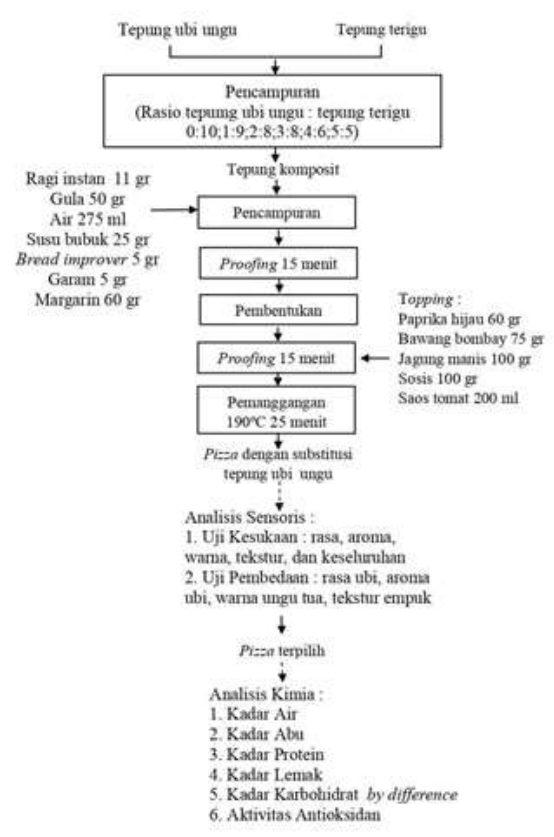

Gambar 1. Diagram Alir Penelitian

Pizza yang dihasilkan kemudian diujikan secara organoleptik ke sejumlah 20 orang panelis tidak terlatih dengan metode scoring. Pengujian organoleptik meliputi kesukaan terhadap rasa, aroma, warna, tekstur, dan keseluruhan, serta uji pembedaan (difference test), meliputi pembedaan terhadap rasa ubi, aroma ubi, warna ubi, dan tekstur empuk. Selanjutnya, pizza yang paling disukai oleh panelis dianalisis proksimat dan uji aktivitas antioksidan. Analisis kadar air metode thermogravimeteri, kadar abu melalui uji pengabuan kering, analisis kadar protein dengan metode Kjedahl, kadar lemak dengan metode soxhlet, dan kadar karbohidrat by difference, sementara aktivitas antioksidan menggunakan metode Radical Scavenging Activity (RSA). Analisis data dilakukan dengan menggunakan uji ANOVA dan uji lanjut Duncan pada selang kepercayaan 5\%. Prosedur penelitian disajikan dalam Gambar 1.

\section{HASIL DAN PEMBAHASAN}

\subsection{Sifat Organoleptik}

Pengujian organoleptik yang dilakukan meliputi kesukaan terhadap rasa, aroma, warna, tekstur, dan keseluruhan. Uji pembedaan (difference test) meliputi pembedaan terhadap rasa ubi, aroma ubi, warna ungu tua, dan tekstur empuk. Analisis organoleptik mempunyai peran utama dalam penilaian flavour. Uji organoleptik adalah cara pengambilan data yang bertujuan untuk mendapatkan informasi terkait sifat bahan makanan dengan menggunakan panca indera manusia (Krissetiana et al., 2020). Terdapat 2 jenis analisis organoleptik yaitu affektif dan analitik. Affektif berhubungan dengan tingkat penerimaan konsumen dan juga pada industri sektor pangan, sedangkan analitik terkait dengan panelis yang sudah terlatih untuk membedakan antar produk (Hasbullah, 2016). Selain aspek gizi dan fungsional, analisis organoleptik dapat dilakukan untuk melakukan evaluasi terhadap produk pangan dari proses produksi, pemeriksaan produk jadi atau pengembangan produkbaru.

\subsubsection{Warna}

Penampakan produk merupakan atribut penting dan menjadi bahan pertimbangan yang digunakan saat memilih sebuah produk oleh konsumen dibandingkan dengan atribut lain. Selain sebagai ciri khas, warna juga bisa memberikan kesan bahwa produk tersebut menarik dan konsumen menganggap bahwa rasa dan kualitas dari produk tersebut baik. Karakteristik produk terwakili oleh warna, aroma, tekstur, dan cita rasa (Dewandari, 2014). Hasil analisis organoleptik terhadap warna disajikan pada Tabel 2 . 
Pizza dengan perlakuan substitusi tepung ubi ungu $0 \%$ disukai karena berwarna tidak ungu tua. Perlakuan subtitusi tepung ubi ungu $10 \%$, $20 \%$, dan $30 \%$ pada produk pizza cukup disukai karena warnanya cenderung tidak ungu tua sementara konsentrasi $40 \%$ dan 50\% karena berwarna ungu tua. Hal ini dikarenakan jarang warna pizza berwarna ke unguan sehingga panelis cenderung menyukai pizza yang memiliki warna seperti pada umumnya. Adanya kenampakan ungu disebabkan kandungan pigmen antosianin yang terdapat pada ubi ungu. Hasil pembedaan terhadap ungu tua didapatkan hasil pada konsentrasi $0 \%$ sangat tidak ungu tua, konsentrasi 10\% tidak ungu tua, 20\% dan 30\% cukup ungu tua serta pada konsentrasi $40 \%$ dan $50 \%$ ungu tua.

\subsubsection{Aroma}

Aroma merupakan respon dari indra pencium manusia saat senyawa volatil dari produk pangan muncul masuk melalui rongga hidung dan dirasakan oleh sistem olifaktori yang dapat terdeteksi pada saat manusia bernafas saat makan. Aroma memiliki peranan penting, karena dapat menambah selera dan minat pada makanan (Tarwendah, 2017). Hasil analisis organoleptik terhadap aroma disajikan dalam Tabel 3.

Berdasarkan Tabel 3, pada pizza dengan perlakuan substitusi tepung ubi ungu $0 \%$ disukai panelis karena tidak beraroma ubi. Konsentrasi $10 \%, 20 \%$, dan 30\% cukup disukai karena cenderung tidak beraroma ubi. Pada perlakuan subtitusi tepung ubi ungu 40\% dan 50\% pizza tidak disukai karena cukup beraroma ubi. Adanya aroma ubi disebabkan oleh penambahan tepung ubi ungu yang mulai terdeteksi pada konsentrasi $40 \%$ dan 50\%. Kecenderungan tidak menyukai pizza dengan konsentrasi $40 \%$ dan $50 \%$ karena panelis belum familiar dan cenderung menyukai yang tidak diberi tambahan tepung ubi ungu. Hasil uji pembedaan terhadap

Tabel 2. Analisis Organoleptik Terhadap Warna

\begin{tabular}{ccc}
\hline $\begin{array}{c}\text { Konsentrasi Tepung } \\
\text { Ubi Ungu }\end{array}$ & $\begin{array}{c}\text { Hasil Uji Kesukaan } \\
\text { terhadap Warna }\end{array}$ & $\begin{array}{c}\text { Hasil Uji Pembedaan terhadap } \\
\text { Warna Ungu Tua }\end{array}$ \\
\hline $0 \%$ & $4,48 \pm 0,68^{\mathrm{c}}$ & $1,08 \pm 0,27^{\mathrm{a}}$ \\
$10 \%$ & $3,38 \pm 0,93^{\mathrm{b}}$ & $2,20 \pm 0,79 \mathrm{~b}$ \\
$20 \%$ & $3,15 \pm 0,86^{\mathrm{b}}$ & $2,83 \pm 0,68^{\mathrm{c}}$ \\
$30 \%$ & $3,08 \pm 1,02^{\mathrm{b}}$ & $3,45 \pm 0,71^{\mathrm{d}}$ \\
$40 \%$ & $2,65 \pm 1,14^{\mathrm{a}}$ & $3,98 \pm 0,97 \mathrm{e}$ \\
$50 \%$ & $2,48 \pm 1,06^{\mathrm{a}}$ & $4,38 \pm 0,81^{\mathrm{f}}$ \\
\hline
\end{tabular}

Keterangan : Angka penilaian untuk uji kesukaan (1) sangat tidak disukai (2) tidak disukai (3) cukup disukai (4) disukai (5) sangat disukai. Angka penilaian untuk uji pembedaan (1) sangat tidak ungu tua (2) tidak ungu tua (3) cukup ungu tua (4) ungu tua (5) sangat ungu tua. Tanda superscript dengan huruf yang berbeda dalam satu kolom menunjukkan hasil yang berbeda signifikan ( $\alpha=5 \%)$.

Tabel 3. Analisis Organoleptik Terhadap Aroma

\begin{tabular}{ccc}
\hline $\begin{array}{c}\text { Konsentrasi Tepung } \\
\text { Ubi Ungu }\end{array}$ & $\begin{array}{c}\text { Hasil Uji Kesukaan } \\
\text { terhadap Aroma }\end{array}$ & $\begin{array}{c}\text { Hasil Uji Pembedaan terhadap } \\
\text { Aroma Ubi }\end{array}$ \\
\hline $0 \%$ & $3,65 \pm 1,00 \mathrm{c}$ & $1,75 \pm 0,90 \mathrm{a}$ \\
$10 \%$ & $3,30 \pm 0,91 \mathrm{bc}$ & $2,05 \pm 0,75 \mathrm{ab}$ \\
$20 \%$ & $3,00 \pm 0,72 \mathrm{ab}$ & $2,28 \pm 0,75 \mathrm{bc}$ \\
$30 \%$ & $3,13 \pm 0,94 \mathrm{ab}$ & $2,40 \pm 0,93 \mathrm{bc}$ \\
$40 \%$ & $2,73 \pm 0,93 \mathrm{a}$ & $2,73 \pm 1,06 \mathrm{c}$ \\
$50 \%$ & $3,00 \pm 0,91 \mathrm{ab}$ & $2,65 \pm 1,27 \mathrm{c}$ \\
\hline
\end{tabular}

Keterangan : Angka penilaian untuk uji kesukaan (1) sangat tidak disukai (2) tidak disukai (3) cukup disukai (4) disukai (5) sangat disukai. Angka penilaian untuk uji pembedaan (1) sangat tidak beraroma ubi (2) tidak beraroma ubi (3) cukup beraroma ubi (4) beraroma ubi (5) sangat beraroma ubi. Tanda superscript dengan huruf yang berbeda dalam satu kolom menunjukkan hasil yang berbeda signifikan ( $\alpha=5 \%$ ). 
aroma ubi menjelaskan jika pada perlakuan konsentrasi $0 \%$ sangat tidak beraroma ubi, konsentrasi 10\%, 20\%, 30\% tidak beraroma ubi dan konsentrasi 40\%, 50\% cukup beraroma ubi.

\subsubsection{Tekstur}

Tekstur adalah karakteristik yang bisa dideteksi oleh indera penglihatan dan indera perasa (Rakhmawati, 2014). Hasil analisis organoleptik terhadap aroma tersaji dalam Tabel 4. Berdasarkan data pada Tabel 4, pada pizza dengan perlakuan substitusi tepung ubi ungu $0 \%$ disukai karena memililiki tekstur empuk, Konsentrasi 10\%, 20\%, dan 30\% cukup disukai karena cukup empuk, serta konsentrasi $40 \%$ dan $50 \%$ pada pizza ubi ungu tidak empuk. Hal ini dikarenakan substitusi parsial ubi ungu akan menurunkan jumlah tepung terigu sehingga akan menurunkan kadar gluten yang berperan dalam pengembangan adonan pizza. Saat adonan pizza tidak mengembang maka tidak terbentuk rongga antara struktur-struktur penyusun pizza dan menyebabkan adonan pizza tidak mengembang (padat) sehingga panelis mengenali hal tersebut dengan tekstur yang tidak empuk.

\subsubsection{Rasa}

Rasa adalah salah satu daya tarik yang mampu memberikan kesan secara cita rasa terhadap produk yang dikonsumsi. Citarasa adalah senyawa yang dapat memberikan persepsi rasa manis, getir, dan asin setelah mencicipi olahan makanan. Rasa merupakan senyawa atau gabungan dua senyawa atau lebih yang mampu memberikan presepsi biologis yang dihasilkan oleh produk pangan melalui indera pengecap (Tarwendah, 2017). Hasil analisis organoleptik terhadap warna disajikan dalam Tabel 5.

Pizza dengan perlakuan substitusi tepung ubi ungu $0 \%$ disukai panelis karena sangat tidak berasa ubi. Konsentrasi 10\%, 20\%, 30\%, 40\%, dan $50 \%$ cenderung tidak disukai karena cukup berasa ubi. Hal ini dikarenakan panelis tidak

Tabel 4. Analisis Organoleptik Terhadap Tekstur

\begin{tabular}{ccc}
\hline $\begin{array}{c}\text { Konsentrasi Tepung Ubi } \\
\text { Ungu }\end{array}$ & $\begin{array}{c}\text { Hasil Uji Kesukaan } \\
\text { terhadap Tekstur }\end{array}$ & $\begin{array}{c}\text { Hasil Uji Pembedaan } \\
\text { terhadap Tekstur Empuk }\end{array}$ \\
\hline $0 \%$ & $4,23 \pm 0,66^{\mathrm{d}}$ & $3,98 \pm 1,00 \mathrm{e}$ \\
$10 \%$ & $3,38 \pm 1,00^{\mathrm{c}}$ & $3,55 \pm 0,88 \mathrm{~d}$ \\
$20 \%$ & $3,15 \pm 0,95 \mathrm{bc}$ & $3,10 \pm 0,67 \mathrm{c}$ \\
$30 \%$ & $2,85 \pm 1,03 \mathrm{~b}$ & $2,93 \pm 1,05 \mathrm{bc}$ \\
$40 \%$ & $2,33 \pm 0,80 \mathrm{a}$ & $2,63 \pm 1,08 \mathrm{ab}$ \\
$50 \%$ & $2,20 \pm 0,79 \mathrm{a}$ & $2,33 \pm 1,05 \mathrm{a}$ \\
\hline
\end{tabular}

Keterangan : Angka penilaian untuk uji kesukaan (1) sangat tidak disukai (2) tidak disukai (3) cukup disukai (4) disukai (5) sangat disukai. Angka penilaian untuk uji pembedaan (1) sangat tidak empuk (2) tidak empuk (3) cukup empuk (4) empuk (5) sangat empuk. Tanda superscript dengan huruf yang berbeda dalam satu kolom menunjukkan hasil yang berbeda signifikan ( $\alpha=5 \%$ ).

Tabel 5. Analisis Organoleptik Terhadap Rasa

\begin{tabular}{ccc}
\hline $\begin{array}{c}\text { Konsentrasi Tepung } \\
\text { Ubi Ungu }\end{array}$ & $\begin{array}{c}\text { Hasil Uji Kesukaan } \\
\text { Terhadap Rasa }\end{array}$ & $\begin{array}{c}\text { Hasil Uji Pembedaan Terhadap } \\
\text { Rasa Ubi }\end{array}$ \\
\hline $0 \%$ & $4,25 \pm 0,74^{\mathrm{c}}$ & $1,50 \pm 0,72^{\mathrm{a}}$ \\
$10 \%$ & $3,53 \pm 1,04^{\mathrm{b}}$ & $2,23 \pm 0,70^{\mathrm{b}}$ \\
$20 \%$ & $3,13 \pm 0,91^{\mathrm{b}}$ & $2,70 \pm 0,88^{\mathrm{c}}$ \\
$30 \%$ & $3,15 \pm 1,00 \mathrm{~b}$ & $2,73 \pm 0,88 \mathrm{c}$ \\
$40 \%$ & $2,38 \pm 0,93^{\mathrm{a}}$ & $3,08 \pm 1,19 \mathrm{~cd}$ \\
$50 \%$ & $2,50 \pm 0,99 \mathrm{a}$ & $3,25 \pm 1,19 \mathrm{~d}$ \\
\hline
\end{tabular}

Keterangan : Angka penilaian untuk uji kesukaan (1) sangat tidak disukai (2) tidak disukai (3) cukup disukai (4) disukai (5) sangat disukai. Angka penilaian untuk uji pembedaan (1) sangat tidak berasa ubi (2) tidak berasa ubi (3) cukup berasa ubi (4) berasa ubi (5) sangat berasa ubi. Tanda superscript dengan huruf yang berbeda dalam satu kolom menunjukkan hasil yang berbeda signifikan ( $\alpha=5 \%$ ) 
terlalu familiar dengan pizza yang diberi substitusi tepung ubi ungu, panelis cenderung menyukai pizza dengan rasa ubi yang tidak muncul.

\subsubsection{Keseluruhan}

Secara keseluruhan, pizza dengan perlakuan substitusi tepung ubi ungu $0 \%$ disukai panelis, konsentrasi 10\%, 20\%,30\% cukup disukai dan pizza dengan subtitusi tepung ubi ungu $40 \%$ dan $50 \%$ tidak disukai. Hal ini menunjukan substitusi parsial tepung ubi ungu cukup disukai sampai konsentrasi $30 \%$. Sementara pizza ubi ungu konsentrasi $40 \%$ dan $50 \%$ ditolak oleh panelis karena panelis menyatakan tidak disukai. Hasil analisis organoleptik penambahan tepung ubi ungu cukup disukai sampai konsentrasi 30\%. Apabila untuk memberikan manfaat antioksidan dari ubi ungu maka dipilih untuk penambahan konsentrasi $30 \%$. Sehingga dapat dipilih satu sampel terbaik untuk uji kimia pada konsentrasi $30 \%$. Hasil analisis organoleptik terhadap keseluruhan disajikan dalam Tabel 6.

\subsection{Analisis Kimia}

Pizza yang paling disukai oleh panelis dianalisis proksimat Selain itu, pizza yang dihasilkan juga dilakukan uji aktivitas antioksidan. Hasil analisis tersaji dalam Tabel 7. Berdasarkan data, pizza dengan penambahan tepung ubi ungu sebanyak $30 \%$ memiliki kadar air sebesar $44,45 \%$, sementara pada pada konsentrasi $0 \%$ sebesar $42,61 \%$. Sebagai salah satu komponen dalam komoditas pangan, air bermanfaat untuk membentuk tingkat keempukan, rasa, dan perubahan reaksi enzimatis dalam produk olahan pangan. Kadar air pada penambahan tepung ubi ungu 30\% lebih tinggi dibandingkan dengan pizza konsentrasi 0\% disebabkan karena kandungan serat pada tepung ubi ungu yang bersifat mengikat air (Dewandari, 2014). Selain itu, adanya substitusi parsial tepung ubi ungu dapat mengikat air karena sifat karbohidrat yang mengikat air. Kadar abu pada perlakuan penambahan tepung ubi ungu $0 \%$ dan $30 \%$ berbeda nyata dengan kadar abu 2,44 (\%db) pada konsentrasi $0 \%$ dan 3,48\% pada konsentrasi $30 \%$. Berdasarkan hasil analisis kadar protein pizza dengan subtitusi parsial $0 \%$ memiliki kadar $12,72(\% d b)$ dan pada konsentrasi 30\% memiliki kadar 10,26 (\%db). Kadar protein pada perlakuan substitusi parsial 0\% lebih tinggi dikarenakan bahan baku yang digunakan tepung protein tinggi, sementara pada substitusi parsial $30 \%$ ubi ungu tidak memilki kandungan protein jenis gluten.

Berdasarkan analisis kadar lemak yang dilakukan pada pizza terpilih, diperoleh hasil bahwa tidak perbedaan nyata yang terjadi diantara semua sampel. Kadar lemak pada substitusi parsial 0\% sebesar 10,75 (\%db) dan 10,57 (\%db) pada substitusi parsial 30\%. Berdasarkan Tabel 7, kadar karbohidrat by difference pizza dengan substitusi parsial 0\% sebesar 74,09 (\%db) dan $75,68 \%$ (\%db) pada substitusi parsial konsentrasi 30\%. (Pamungkas, 2011) menyatakan jika penurunan kadar karbohidrat pada saat proses fermentasi disebabkan oleh pemecahan gula kompleks menjadi sederhana yang mudah dicerna oleh kapang.

Warna pada ubi ungu disebabkan adanya zat warna alami yaitu antosianin yang berfungsi sebagai antioksidan. Antosianin merupakan senyawa polifenol yang efektif menangkap

Tabel 6. Hasil Analisis Organoleptik Terhadap Keseluruhan

\begin{tabular}{cc}
\hline Konsentrasi Tepung Ubi Ungu & Hasil Uji Kesukaan terhadap Keseluruhan \\
\hline $0 \%$ & $4,30 \pm 0,69 \mathrm{~d}$ \\
$10 \%$ & $3,63 \pm 0,95 \mathrm{c}$ \\
$20 \%$ & $3,30 \pm 0,79 \mathrm{bc}$ \\
$30 \%$ & $3,20 \pm 0,94 \mathrm{~b}$ \\
$40 \%$ & $2,58 \pm 0,84 \mathrm{a}$ \\
$50 \%$ & $2,58 \pm 0,84 \mathrm{a}$ \\
\hline
\end{tabular}

Keterangan : Angka penilaian untuk uji kesukaan (1) sangat tidak disukai (2) tidak disukai (3) cukup disukai (4) disukai (5) sangat disukai. Tanda superscript dengan huruf yang berbeda dalam satu kolom menunjukkan hasil yang berbeda signifikan ( $\alpha=5 \%$ ). 
Tabel 7. Hasil Analisis Proksimat Pada Pizza Terpilih dan Kontrol

\begin{tabular}{lcc}
\hline \multirow{2}{*}{ Analisis Kimia } & \multicolumn{2}{c}{ Konsentrasi Tepung Ubi Ungu } \\
\cline { 2 - 3 } & $\mathbf{0 \%}$ & $\mathbf{3 0 \%}$ \\
\hline Air (\%wb) & $42,61 \pm 0,52 \mathrm{a}$ & $44,45 \pm 0,09 \mathrm{~b}$ \\
Abu (\% db) & $2,44 \pm 0,25^{\mathrm{a}}$ & $3,48 \pm 0,11 \mathrm{~b}$ \\
Protein (\% db) & $12,72 \pm 0,48^{\mathrm{a}}$ & $10,26 \pm 0,23 \mathrm{~b}$ \\
Lemak (\% db) & $10,75 \pm 0,26^{\mathrm{a}}$ & $10,57 \pm 0,11^{\mathrm{a}}$ \\
Karbohidrat (\% db) & $74,09 \pm 0,47 \mathrm{a}$ & $75,68 \pm 0,33 \mathrm{~b}$ \\
Aktivitas antioksidan (\%) & $35,92 \pm 1,54 \mathrm{a}$ & $71,26 \pm 2,86 \mathrm{~b}$ \\
\hline
\end{tabular}

Keterangan : Superscript notasi huruf kecil yang berbeda menunjukan berbeda nyata $(\mathrm{p}>0,05)$

radikal bebas. Antioksidan bermanfaat mencegah oksidasi molekul penghasil radikal bebas (Sari et al., 2021).Terdapat bermacam metode analisis aktivitas antioksidan, salah satunya dengan metode Radical Scavening Activity (RSA). Berdasarkan Tabel 7, analisis aktivitas antioksidan menunjukan bahwa pada pizza dengan penambahan tepung ubi ungu $30 \%$ sebesar $71,26 \%$, sedangkan pada konsentrasi $0 \%$ sebesar $35,92 \%$.

\section{KESIMPULAN DAN SARAN}

\subsection{Kesimpulan}

Penambahan tepung ubi ungu mempengaruhi sifat organoleptik dan sifat kimia pizza yang dihasilkan. Pizza dengan substitusi parsial tepung ubi ungu cukup disukai panelis sampai konsentrasi $30 \%$. Adanya substitusi tepung ubi ungu dalam pembuatan pizza dapat meningkatkan kadar air, kadar abu, kadar karbohidrat by difference, dan aktivitas antioksidan, namun tidak mempengaruhi kadar lemak dan menurunkan kadar proteinnya.

\subsection{Saran}

Diperlukan penelitian lebih lanjut tentang aktivitas antioksidan pizza ubi ungu pada berbagai kondisi dan lama waktu penyimpanan.

\section{DAFTAR PUSTAKA}

Darmawansyah, A., dan Ninsix, R. 2016. Studi pembuatan roti manis dengan substitusi tepung ubi jalar kuning. Jurnal Teknologi Pertanian, 5(1): 30-36. https://doi.org/ 10.32520/jtp.v5i1.88
Dewandari, D. 2014. Kajian penggunaan tepung ubi jalar ungu (Ipomea batatas L.) terhadap karakteristik sensoris dan fisikokimia pada pembuatan kerupuk. Jurnal Teknosains Pangan, 3(1): 35-52. https://www.ilmupangan.fp.uns.ac.id/

Hasbullah, U. H. A. 2016. Sifat sensoris dan principal component analysis tepung suweg di Karisidenan Surakarta. Jurnal Ilmiah Teknosains, 2(2): 126-130 https:/ /doi.org/10.26877/jitek.v2i2/nov.1201

Husna, N. El, Novita, M., dan Rohaya, S. 2013. Kandungan antosianin dan aktivitas antioksidan ubi jalar ungu segar dan produk olahannya. Agritech, 33(03): 296302. https://doi.org/10.22146/ agritech.9551

Krissetiana, H., Kiswanto, Y., dan Suyanto, R. 2020. Perlakuan proofing terhadap sifat sensoris roti Mocaf. Jurnal Teknologi Dan Industri Pangan, 5(1):1-11 https:// doi.org/10.33061/jitipari.v5i1.3638

Murtiningsih, S. 2011. Membuat Tepung Umbi dan Variasi Olahannya. PT. AgroMedia Pustaka. Jakarta Selatan.

Pamungkas, W. 2011. Teknologi fermentasi, alternatif solusi dalam upaya pemanfaatan bahan pakan lokal. Media Akuakultur, 6(1): 43. https://doi.org/10.15578/ ma.6.1.2011.43-48

Rakhmawati. 2014. Pemanfaatan tepung umbi garut (Maranta arundinacea L.) sebagai pengganti terigu dalam pembuatan biskuit 
tinggi energi protein dengan penambahan tepung kacang merah (Phaseolus vulgaris L.). Jurnal Teknosains Pangan, 3 (1): 314.

Sari, M., Ulfa, R. N., Marpaung, M. P., dan Purnama. 2021. Penentuan aktivitas antioksidan dan kandungan flavonoid total ekstrak daun papasan (coccinia grandis l.) berdasarkan perbedaan pelarut polar. KOVALEN: Jurnal Riset Kimia, 7(1): 30-41. https://doi.org/ 10.22487/kovalen.2021.v7.i1.15437

Tarwendah, I. P. 2017. Jurnal review: Studi komparasi atribut sensoris dan kesadaran merek produk pangan. Jurnal Pangan Dan Agroindustri, 5(2): 66-73. 